doctor's wife. Although our own assessments may have been biased because we knew the occupation of the patients, we should have influenced the results consistently, as we were testing the assumption that it was doctors as well as their wives who had more complications from their illnesses than one would expect. Similarly, one of our reasons for adopting this particular experimental approach was that we wished to cause as little disruption of normal ward behaviour as possible, so that the nurses did not know that their own notes had been used as a measure of behaviour. Because of these points, we think that we have observed a real difference in nursing and medical staff behaviour towards one group of their patients. Because of the limitations imposed by the design of our study, we conclude that this difference in behaviour is not related to social class, parity, race, or age, and may be related to the occupation of the patient's husband.

What is more intriguing is why the nursing and medical staff should view minor psychiatric problems so differently. In all three groups comments are duly made about unusual behaviour in the mothers, despite the different ways in which the problems arose. The way these problems were subsequently managed, however, differs. An explanation may be that the medical staff do not perceive the doctors' wife as their patient, as she has a live-in physician who will look after her and her baby. Nevertheless, her husband expects her to behave very differently from his own patients, and consequently she is effectively ignored by everyone dealing with her emotional care. ${ }^{4}$ On the other hand, the physician-wife is hardly going to think of herself as a patient, let alone in need of medical help. ${ }^{23}$

What is clear, however, is not that being a special patient is particularly harmful but that by not recognising this type of patient quite obvious and simple problems may be missed.

We thank Dr E Lewis, Dr $\mathrm{H}$ Bourne, $\mathrm{Mr} \mathrm{M}$ Pawson, and $\mathrm{Dr} \mathrm{H}$ Jolly for thier comments and help and $\mathrm{Dr} \mathrm{K}$ McCrae for valuable statistical advice. We also thank the nurses and midwives on the postnatal wards for their co-operation and good humour and Mrs Jane Haile for preparing this manuscript.

\section{References}

${ }^{1}$ Office of Population Censuses and Surveys. Classification of occupations. London: HMSO, 1970.

2 Allibone A, Oakes D, Shannon HS. The health and health care of doctors. f $R$ Coll Gen Pract $1981 ; 31: 728-34$

${ }^{3}$ Murray RW. The health of doctors: a review. $\mathcal{f} R$ Coll Physicians 1978 ; 12:403-15.

${ }^{4}$ Anonymous. Do sick doctors need more than the GMC. Br Med 71981 ; 282:1-2.

5 Scarlett EP. Doctor out of Zebulun: the doctor's wife. Arch Intern Med 1965;115:351-7.

(Accepted 11 May 1982)

\title{
Cost of anaesthesia
}

\author{
B A ASTLEY, J SECKER WALKER
}

\begin{abstract}
The major contributory factor to the cost of anaesthesia today are the increases in medical salaries that have kept pace with inflation, commanding $68 \%$ of the total expenditure. The current position has been compared with that of 20 years ago. This outline could be used as a framework for departmental budgeting.
\end{abstract}

\section{Introduction}

There have been many reports on the cost of anaesthesia over the past 20 years. Simpson ${ }^{1}$ and Bailey ${ }^{2}$ in 1978 examined in detail the price of drugs and compared and contrasted different anaesthetic techniques; they pointed out economies that could be made. Other authors ${ }^{3}{ }^{4}$ combined the cost of drugs and staffing to give an overall cost of anaesthesia. Simpson ${ }^{1}$ reported that despite inflation the cost of drugs had stayed fairly constant over the preceding 17 years, but it was subsequently pointed out $^{5}$ that a "new and much larger cost is that of disposable equipment."

Shackleton $^{3}$ quoted an average of $£ 3.69$ per anaesthetic in Southampton. Twenty years later the figure has risen to $£ 29.68$ in a London teaching hospital, an increase of eight times. We

\footnotetext{
Department of Anaesthetics, University College Hospital, London WC1

B A ASTLEY, MB, FFARCS, senior registrar in anaesthetics

J SECKER WALKER, MB, FFARCS, consultant anaesthetist
}

have investigated the major contributing factors to the total cost of anaesthesia by considering in turn drugs, equipment and servicing, and medical and nursing staff.

\section{Cost of drugs}

The prices of drugs are based on the cost plus VAT as obtained from the hospital pharmacy at the end of 1980. All substances have been considered except liquid oxygen, as this is delivered throughout the hospital and its contribution to the cost of an anaesthetic is negligible.

The total drug bill for 1980 was $£ 44032$. Between them nitrous oxide, thiopentone, fentanyl, and halothane accounted for $56 \%$ of this (table I). Nitrous oxide, in clinical use since 1867, still remains the largest single item on the anaesthetic drug bill. It is used instead of nitrogen to provide the non-oxygen content of each tidal volume. It is also an excellent analgesic (300-360 $1 / \mathrm{h}$ may be used in each anaesthetic). Despite a view currently held by some anaesthetists that in the future anaesthesia will be totally intravenous, nitrous oxide will probably remain a constant ingredient in the vast majority of anaesthetics. The figure for halothane was $11.2 \%$, compared with $37.1 \%$ in Sheffield in $1966,{ }^{4}$ the fall being due partly to awareness of its potential dangers, partly to a reduction in cost from $£ 9.96$ per $250 \mathrm{ml}$ when it was introduced to $£ 6.4$ per $250 \mathrm{ml}$, and partly to increased use of neurolept and local anaesthetic techniques.

Fentanyl contributed $11.5 \%$ to the total drug bill, and muscle relaxants $22.3 \%$, as compared with $5.3 \%$ in $1966 .{ }^{4}$ The expense of the most recent inhalation agent, ethrane, at $£ 28.75$ per $250 \mathrm{ml}$, accounting for $4.7 \%$ of the total drug bill, should be contrasted with the price of trichlorethylene at $£ 1.4$ per $500 \mathrm{ml}$.

The current cost of anaesthesia for a major operation such as a hysterectomy (table II) lasting an hour was $£ 3.01$ when halothane was used, increased to $£ 4.96$ when fentanyl was used, but more than 
TABLE I-Cost of various drugs

\begin{tabular}{|c|c|c|c|}
\hline Drug & $\begin{array}{c}1980 \\
(£)\end{array}$ & $\begin{array}{c}\text { Total spent } \\
(£)\end{array}$ & $\%$ of total \\
\hline Thiopentone $0.5 \mathrm{~g}+\mathrm{H}_{2} \mathrm{O}$ & 0.71 & 6523 & 14.8 \\
\hline Methohexitone $100 \mathrm{mg}$ & 0.47 & $227 \cdot 5$ & 0.5 \\
\hline Althesin $5 \mathrm{ml}$ & 1.20 & $1177 \cdot 6$ & $2 \cdot 6$ \\
\hline Propanidid & 0.44 & $30 \cdot 6$ & $0 \cdot 1$ \\
\hline Etomidate & $1 \cdot 16$ & $577 \cdot 2$ & 1.3 \\
\hline Diazepam & 0.24 & $1482 \cdot 3$ & $3 \cdot 3$ \\
\hline Pethidine $2 \mathrm{ml} / 100 \mathrm{mg}$ & 0.06 & $384 \cdot 4$ & $0 \cdot 8$ \\
\hline Pethidine $5 \mathrm{ml} / 50 \mathrm{mg}$ & 0.25 & $134 \cdot 6$ & $0 \cdot 30$ \\
\hline Fentanyl $0 \cdot 2 / 2 \mathrm{ml}$ & 0.45 & 1616.8 & 3.67 \\
\hline Naloxone & $2 \cdot 47$ & $1362 \cdot 2$ & 3.09 \\
\hline Pentazocine $2 \mathrm{ml} / 60$ & 0.64 & $302 \cdot 4$ & 0.68 \\
\hline Papaveretum and hyoscine & 0.07 & $545 \cdot 7$ & $1 \cdot 23$ \\
\hline Suxamethonium & 0.39 & $3219 \cdot 0$ & $7 \cdot 3$ \\
\hline $\begin{array}{l}\text { Curare } \\
\text { lats }\end{array}$ & 0.75 & 3803.8 & 8.6 \\
\hline Pancuronium & $0 \cdot 70$ & $2272 \cdot 0$ & $5 \cdot 15$ \\
\hline Alcuronium & 0.50 & 379.5 & 0.86 \\
\hline Gallamine & 0.22 & $211 \cdot 2$ & 0.47 \\
\hline Neostigmine & 0.06 & $254 \cdot 4$ & 0.57 \\
\hline Atropine & 0.04 & $561 \cdot 0$ & $1 \cdot 27$ \\
\hline Halothane $/ 250 \mathrm{ml}$ & $6 \cdot 42$ & 4945.0 & \\
\hline Ether $/ 500 \mathrm{ml}$ & 2.01 & $210 \cdot 2$ & 0.47 \\
\hline Trilene $/ 500 \mathrm{ml}$ & 1.43 & $25 \cdot 7$ & 0.058 \\
\hline Enflurane $/ 250 \mathrm{ml}$ & $\begin{array}{r}28.75 \\
3.99\end{array}$ & $\begin{array}{l}2098 \cdot 7 \\
8232 \cdot 0\end{array}$ & $\begin{array}{r}4 \cdot 76 \\
18.69\end{array}$ \\
\hline$s$ & 3.99 & 82 & 18.69 \\
\hline
\end{tabular}

TABLE II-Cost of hysterectomy lasting one hour

\begin{tabular}{|c|c|c|c|c|}
\hline & $\begin{array}{l}\text { Present } \\
\text { estimate } \\
1980\end{array}$ & Total & Bailey $^{2}$ & Total \\
\hline \multirow[t]{2}{*}{$\begin{array}{l}\text { Thiopentone } \\
\text { Suxamethonium } \\
\text { Pancuronium } \\
\mathrm{N}_{2} \mathrm{O} \\
\mathrm{O}_{2} \\
\mathrm{H}^{2} \text { lothane } \\
\text { Atropine } \\
\text { Neostigmine } \\
0 \cdot 5 \mathrm{~g} \text { fentanyl instead of halothane } \\
\text { Fentanyl and naloxone instead of } \\
\text { halothane }\end{array}$} & $\begin{array}{l}0.71 \\
0.39 \\
1.14 \\
0.30 \\
0.04 \\
0.30 \\
0.08 \\
0.05 \\
1.95\end{array}$ & $\begin{array}{l}£ 3.01 \\
£ 4.66\end{array}$ & $\begin{array}{l}0.32 \\
0.18 \\
0.52 \\
0.28 \\
0.03 \\
0.23 \\
0.04 \\
0.07 \\
0.99\end{array}$ & $\begin{array}{l}£ 1 \cdot 67 \\
£ 2 \cdot 42\end{array}$ \\
\hline & $2 \cdot 47$ & $£ 7.43$ & & \\
\hline $\begin{array}{l}3 \text { ECG electrodes } \\
\text { Butterfly needle } 23 \mathrm{~g} \\
\text { Syringes and needles }\end{array}$ & $\begin{array}{l}0 \cdot 66 \\
0 \cdot 27 \\
0 \cdot 24\end{array}$ & $£ 1 \cdot 17$ & & \\
\hline $\begin{array}{l}\text { Intravenous drip: } \\
\text { Angiocath } 16 \mathrm{~g} \\
\text { Drip set } \\
\text { 1 litre Hartmann's solution } \\
\text { Sticking plaster }\end{array}$ & $\begin{array}{l}0.38 \\
0.65 \\
0.99 \\
0.01\end{array}$ & $£ 2.03$ & & $£ 3.20$ \\
\hline
\end{tabular}

doubled if the opiate antagonist, naloxone, was added. The cost of anaesthesia may have remained fairly constant between 1960 and 1978, but in the past two years prices have increased appreciably from $£ 1 \cdot 66^{2}$ to $£^{3} \cdot 01$.

\section{Equipment and servicing}

Monitoring equipment has improved so much over the past decade that it is now our routine to make use of a continuous ECG during anaesthesia. Disposable intravenous infusion equipment is also routinely used for major surgery, and it is our practice to use autoclavable red rubber tubes, which are included in the total cost under the central sterile supplies depot (CSSD) heading, that cost $£ 5200$ a year (table III).

Disposable equipment costs as much as drugs, $£ 3.22$ as compared with $£ 3.01$ (table II). It accounted for up to $51 \%$ of the cost, com-

TABLE III-Factors affecting the cost of anaesthesia

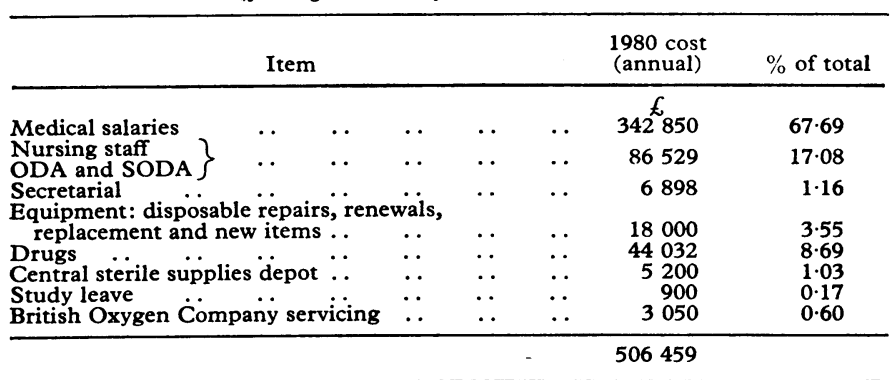

(S)ODA $=$ (Senior) operating department assistants: pared with the estimated $68 \%$ in $1978 .{ }^{5}$ Drip sets, cannulas, dressings, needles, etc, are provided from a separate stores budget for the whole hospital, while the anaesthetic equipment budget is separately liable for endotracheal tubes, laryngoscopes, and repair and replacement of anaesthetic and monitoring equipment; the three-monthly service contract with the British Oxygen Company also comes out of the equipment budget (table III)

The total cost of equipment, servicing the equipment, and CSSD amounts to $5 \%$ of the total budget. Depreciation is allowed for by a replacement programme and the equipment budget is uplifted for inflation annually.

\section{Medical and nursing salaries}

Medical staff salaries accounted for $61 \%$ of the total anaesthetic budget in $1960 .^{3}$ The percentage has risen to nearly $70 \%$ (table III), and we have therefore calculated our session availability ${ }^{4}$ as follows:

Consultants 54 theatre sessions $\times 46$ weeks 2484

Four senior registrars $\times 9$ theatre sessions $\times 46$ weeks $\quad 1656$

Five registrars $\times 9$ theatre sessions $\times 47$ weeks

Three SHOs $\times 9$ theatre sessions $\times 47$ weeks 1269

7524

An intensive care unit commitment requires one full-time registrar covering $10 \times 52=520$ sessions, therefore total available theatre sessions $=7524-520=7004$. These figures take into account annual leave, study leave, teaching sessions, and sickness as no locums are employed.

In 198016227 anaesthetics were given in the whole theatre group (NHS). From this we can deduce efficiency

$$
=\frac{16277}{7004}=2 \cdot 32 \text { cases } / \text { session }
$$

This compares favourably with the 1966 estimate $^{4}$ for Sheffield, which worked out at 1.97 cases/session.

Medical salaries are the largest item contributing towards the cost of an anaesthetic, closely followed by nursing and operating department assistants' salaries (table III). We employ one sister, seven State-registered nurses, seven State-enrolled nurses, three operating department assistants, and two senior operating department assistants.

We have not estimated for power, heat, rates, and water, nor for any items that come under "hotel" services in district budgeting.

\section{Total cost}

The "basic" cost of an anaesthetic is common to operations carried out in either the private or NHS sectors, since both share the following facilities:

Nursing staff salaries
Equipment budget
Drugs
CSSD
British Oxygen Company servicing

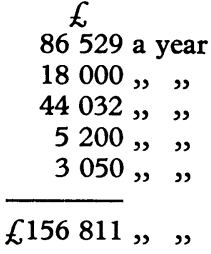

In the year ending December 1980, 16277 NHS patients and 2167 private patients were anaesthetised. The basic cost of an anaesthetic is therefore

$$
\frac{156811}{18444}=£ 8 \cdot 50
$$

The additional cost for an anaesthetic in the NHS includes

$\begin{array}{lc} & £ \\ \text { Medical salaries } & 342850 \text { a year } \\ \text { Secretarial } & 5898, ", \\ \text { Study leave } & 900 ”, \\ & £ 349648\end{array}$

The additional salary cost of an anaesthetic in the NHS is therefore $\frac{349648}{16277}=£ 21 \cdot 48$

and the total average cost $£ 8 \cdot 50+£ 21 \cdot 48=£ 29 \cdot 98$.

In 1979 the figure was $£ 22$ in this hospital, and in 1959 it was estimated with overheads at $£ 3.69$. 


\section{Discussion}

From the figures given it can be seen that $85 \%$ of the total budget is devoted to staff salaries. During a period of economic recession budget holders may be required to take a cut in their budget. A $2 \%$ cut would represent $£ 10000$, and it is not possible to extract that sort of sum without reducing the numbers of staff employed.

Purely from an economic view point the Scandinavian system of employing nurse anaesthetists instead of junior doctors in our department would require 20 nursing sisters at about $£ 6000$ a year- $£ 120000$. Our present consultant staff of seven wholetime equivalents costs $£ 185000$ a year.

Our current bill for medical salaries is $£ 342850$ (consultants $£ 185000$, junior doctors $£ 157850$ ) so that by employing nurses instead of junior doctors we would save $£ 37850$, nearly equivalent to the total cost of drugs.

Functional budgeting for clinical departments will probably become the normal method by which district management teams control their overall budget. Secker Walker ${ }^{6}$ has indicated that this has both advantages and disadvantages, with a defined equipment budget uplifted annually for inflation comes the ability to plan and execute a rational equipment programme and is one of the major advantages of functional budgeting. It requires the approval of the district management team to transfer money between staff and non-staff headings, but our experience has been that this has not been a problem and allows a useful degree of flexibility. Posts unavoidably vacant for a month can produce a useful saving at the end of the year to help purchase a special bit of equipment.

To be a clinical budget holder requires close attention to the control of the budget and this does take time-and is not recompensed. Furthermore, the budget holder is required to make difficult decisions on competing claims-an expensive study leave trip may be equivalent to a new ventilator.

We hope that the data provided here can help other departments negotiate for a realistic clinical budget.

We thank both the pharmacy department and the stores and supplies department for their help and Miss R Hodgson for secretarial help.

\section{References}

1 Simpson PM. The cost of anaesthetic drugs and equipment. Anaesthesia 1978;33:53-9.

2 Bailey PW. Pricing of anaesthetic techniques. Anaesthesia 1978;33:235-41.

${ }^{3}$ Shackleton P. The economics of anaesthesia. Anaesthesia 1960;15:229-34.

4 Murray Wilson A. What price anaesthesia? An investigation into costs. Br Med F 1966;ii:1190-2.

5 Arthurs GJ, Latto IP, Jenkins JRE. Cost of anaesthetic drugs and disposable apparatus. Anaesthesia $1978 ; 33: 645-6$.

${ }^{6}$ Secker Walker J. A year's experience of functional budgeting in a clinical department. Anaesthesia 1981 ;36:316-8.

\section{MATERIA NON MEDICA}

February 24: to the British Library to see the "Famous Books in the History of Science" exhibition

And to suffer the almost immediate frustration of it closing at $5 \mathrm{pm}$ ! What opportunity for enlightenment does this afford to those of us who do not live within a stone's throw of the charmed circle of Bloomsbury? The British library?

But still, a valuable exhibition, apparently designed to show that important scientific discoveries over the centuries (fourteenth to early twentieth, in Europe alone) have been made by people who could write so clearly that anybody, from their contemporaries to us, might follow their ideas without hindrance. Is this a valid observation, or does it demonstrate bias in the selection of works included ? One point about written communication across the centuries which was clearly, bu tacitly, made was that one stands to enjoy the maximum future readership by writing in the "most advanced" language available-people paused over Harvey's De motu cordis et sanguinis (1628), but pored over Hooke's Micrographia: or some physiological descriptions of minute bodies made by magnifying glasses (1665). A lesson for those of us who don't even "speak" Basic yet?

It was interesting to trace the progress of the Renaissance northwards across Europe by following chronologically the cities of publication of the works on show. The first printed one was Robertus Valturius's De re militari (1472) from Venice, the city which dominated the early part of the exhibition. Basle and Nuremburg then crept in, followed by Paris, Leyden, London, Prague, Edinburgh, and Frankfurt. It seemed sad that Oxford's first selected offering was Boyle's New experiments physico-mechanical touching the spring of air published in 1662, nearly two hundred years after the University Press came into business (1478). From the eighteenth century on London about held her own against the combined might of the German presses, other centres pretty well fading out. Was it significant or accidental that there were no papers from outside Europe?

Medicine was fairly represented. The page at which Johannes de Ketham's Fasciculo di medicina (Venice, 1493) was opened illustrated the origins of two pieces of university jargon: a picture of a dissection, with the students standing around while somebody got on with the cutting, a "reader" read aloud the text they were following, and a "demonstrator" actually pointed with a stick to the relevant part. I particularly enjoyed seeing the Guildbook of the barber surgeons of York (circa 1500) whose illustration of men of the four temperaments is so often used to help explain the Galenic tradition. An old friend! However, I did feel it would have been valuable, if possible, to emphasise the early existence of critical medical thinking by including that "lecture note" of preconquest England-the Leechbook of Bald.VIRGINIA ALUN JONES, research senior house officer, Cambridge.

\section{Below-deck lecture}

The idea of a conference on HMS Belfast intrigued me and getting to it was not difficult: a walk from London Bridge Station along Tooley Street-hardly changed since Dickens's day-to the dock on the South Bank near Tower Bridge where the cruiser is moored.

The lecture theatre, which held about 100, was intimate and the equipment simple; so nothing was likely to go wrong except that machinery projecting from the low roof provided the risk of a tall speaker being stunned as he stepped forward to the lectern. It had a typical below-deck décor, a maze of pipes and ventilation shafts. My talk, aptly as it turned out, concerned the problems of the speaker. All went well until extraneous sounds started, the rhythm being a simple crescendo e poco a poco morendo-soon diagnosed as the trampling of feet from groups of tourists above. Then staccato noises were superimposed: those of gun fire and dive bombers as small boys, clambering over an anti-aircraft gun, found the slot where $10 \mathrm{p}$ started a taped record of a battle of the last war-but fortunately distant and muffled because of the intervening deck. As the penultimate slide came up, a door opened and several visitors with fancy hats appeared before the audience-not, as some suggested, pre-arranged as a finale to my talk, but an accidental intrusion in mistake for the engine room or loo.

Yet I would go again to a meeting there, though preferably not during the Easter holiday. The narrow corridors provide contacts, both mental and physical, with other participants and, as is often said, meetings are for meeting people. No temptations to escape lurk nearby and it is unlikely that any talk will be so confusing as to cause a distraught listener to fling himself into the Thames. For respite from staring at slides one steps on to the deck and gazes at the superb panorama of the City of London opposite where the shapes of the dome of St Paul's, the Monument, and the Tower of London act as foils to the rectangular geometry of the skyscrapers which tower above them. - CLIFFORD HAWKINS, Birmingham. 